\title{
УДК 303.519.8
}

DOI: 10.18523/2617-9067.2019.2.16-22

Пугачова О.Г.

\section{АГЕНТНЕ МОДЕЛЮВАННЯ ПОЛІТИКИ ПЕРЕРОЗПОДІЛУ ДОХОДІВ}

У статті проаналізовано результати агентного моделювання впливу податкової і трансферної політики на соціальну структуру суспільства. За допомогою комп'ютерних експериментів перевірено різні податкові режсим. Показано, щуо модель пошуку ренти змінює соціальну структуру та обмежує економічний потенціал суспільства через придушення економічно активної частини середнього класу. У статті також привернуто увагу до агентного моделювання як інструментарію дослідження динаміки поведінки складних систем.

Ключові слова: складна система, конфліктна взаємодія, рівновага, соціальний порядок, модель пошуку ренти.

На відміну від ортодоксальної економічної теорії, рівновага не $є$ ключовою концепцією в соціології. У центрі уваги соціології є соціальний порядок, виникнення якого передбачає емерджентність складних систем. 3 погляду теорії складних систем, емерджентність є новим атрибутом цілого, що виникає в результаті взаємодії і взаємозв'язку частин (Christakis \& Fowler, 2009 , p. 26). Особливістю емерджентності $є$ те, що вона виникає, iї не можна побудувати. Дуглас Нортон, лауреат Нобелівської премії, так говорив про соціальні інститути Свропи: «Ми знаємо, як влаштовані наші інститути, але ми не розуміємо, як їх сконструювати» (як цит. у газеті «Коммерсантъ», 2006). Тому завдання проведення соціальних змін, які б приводили до бажаного соціального порядку, виявляється занадто складним. А втручання в соціальний порядок може мати непередбачувані наслідки.

Соціальний порядок тісно пов'язаний з соціальними інститутами, які підтримують соціальний порядок і стабільність у суспільстві. Серед актуальних питань сьогодення є загроза стабільності інституту демократії(democratic backsliding). Як стверджують Кароліна Візнер та ін. (Wiesner et al., 2019, p. 2), бракує робіт, у яких би досліджувались обставини виникнення нестабільності демократичних інститутів. Основну увагу приділено обставинам падіння авторитарних режимів та поширення демократії у світі. Але дестабілізацію демократії до такої міри, що вона не може вже вважатися демократією, здебільшого розглядають як окремі випадки. Як показують дослідження (World Values Survey, 2014), громадяни багатьох демократичних країн усе менше задоволені своїми інституціями і їх дедалі більше приваблюють альтернативні, навіть автократичні форми режиму.

В Україні ж рівень недовіри громадян до суспільних інститутів є безпрецедентним. За даними дослідження, яке провів Центр Разумкова в лютому 2019 р., державному апарату не довіряють $83 \%$ опитаних, Верховній Раді України - $82 \%$, Уряду України - $75 \%$, Президенту України - 71 \%, Прокуратурі - 70 \%, Національному банку України - 68 \%, Верховному Суду - 65 \%, Антикорупційному суду - $62 \%$ (Центр Разумкова, 2019).

На думку Кароліни Візнер та ін. (Wiesner et al., 2019, р. 6), вчені, що досліджують процеси демократії, мають відійти від аргументів на основі статичної рівноваги до більш динамічних рамок, які краще підходять для того, щоб зрозуміти, наскільки стійкі рівноваги до збурень. Деякі збурення можуть викликати тимчасову нестабільність. Інші можуть спричиняти зміни, що посилюються, а в довгостроковій перспективі призводять до переходу від демократії до недемократії, тобто до іншого соціального порядку.

Серед факторів, що впливають на політичні процеси та дестабілізують демократичні інституції, слід зазначити зростання економічної нерівності. Як стверджують Пейдж і Гіленс (Page \& Gilens, 2017, as cited in Wiesner et al., p. 10), здоров'я демократії тісно пов'язане зі станом економічної нерівності. Демократія передбачає рівність впливу на соціальні інститути, але в умовах економічної нерівності найбільш впливові соціальні актори можуть переформувати соціальні інститути на свою користь, що обмежує можливість громадян впливати на процес ухвалення державних рішень і запускає самопідтримувальну 
траєкторію (self-reinforcing trajectory): збільшення влади $\rightarrow$ зростання економічної нерівності $\rightarrow$ збільшення влади $\rightarrow \ldots \rightarrow$ руйнування демократії. На жаль, процес саморуйнування соціального порядку в Україні зазнав загрозливих масштабів, що потребує уваги до досліджень динаміки соціальної системи в умовах нестабільності та невизначеності.

Це дослідження присвячене аналізу впливу політики перерозподілу доходів на соціальну структуру суспільства. Традиційно податкову політику вважають важливим інструментом, що стримує економічну нерівність та стимулює економічне зростання.

Проте сьогодні соціальна нерівність стала ключовим викликом для політиків усього світу. Згідно $з$ доповідями Організації економічного співробітництва та розвитку (ОЕСР), розрив між багатими та бідними в більшості країн ОЕСР перебуває на найвищому рівні за останні 30 років. Сьогодні середній дохід 10 \% найбагатшого населення приблизно в 9 разів перевищує дохід $10 \%$ найбіднішого, коефіцієнт Джині за останні два десятиліття збільшився на 3 пункти (OECD, 2014). Як свідчать дослідження, довгострокове збільшення нерівності доходів істотно стримує економічне зростання (Cingano, 2014).

Зростання нерівності є складною проблемою, що охоплює безліч факторів, як-от глобалізація, технологічні, економічні та соціальні зміни. Водночас проблема нерівності багатств має свою власну еволюцію, яка, своєю чергою, виявляє нові аспекти цього вузлового питання. Як зазначив Джозеф Стігліц, у центрі уваги цієї проблеми $€$ механізм пошуку ренти і правил гри. Пошук ренти означає практику отримання багатства не через діяльність, яка має економічну цінність, а через вилучення доходу з інших (Stiglitz et al., 2015). Соціальні привілеї, влада і вплив дають можливість лобіювати деякі правила гри, які є вигідними для невеликої соціальної групи. Тобто спостерігається еволюція економічної нерівності: від моделі конкурентоспроможної продуктивності до моделі створення ренти та правил гри.

Метою цього дослідження $є$ аналіз наслідків зовнішнього втручання в механізм соціальної взаємодії як складної системи соціального обміну, що збалансовує витрати та винагороди. Серед відомих моделей соціальної взаємодії можна виділити моделі «хижак-жертва», «дилема в’язня» (Плотинский, 2001) та модель переходу до кооперативної поведінки (Nowak, 2006). У цій роботі привертається увага до використання агентного моделювання як інструментарію дослідження динаміки поведінки складної системи.
Застосування потенціалу агентного моделювання виявилось перспективним 3 погляду дослідження динаміки складних соціальних систем іє сьогодні експериментальною лабораторією вивчення процесів самоорганізації в суспільстві (Epstein \& Axtell, 1996; Squazzoni, 2012). Ця нова парадигма моделювання дає змогу побачити «виникнення» процесів на макрорівні із взаємодії елементів системи на мікрорівні. Агентне моделювання - це специфічний клас комп'ютерних моделей, призначених для виявлення та кращого розуміння емерджентних властивостей поведінки складних систем. Як вказував визнаний авторитет у галузі агентного моделювання Джошуа Епштейн, розуміння емерджентності складної системи передбачає вміння виростити цей феномен (Epstein \& Axtell, 1996, p. 19-20): «Моделювання штучного суспільства може змінити те, як ми думаємо, коли щось пояснюємо в суспільних науках. Що є поясненням суспільного явища, яке ми спостерігаємо? Можливо, настане час, коли замість питання: “Чи можемо ми це пояснити?”, ми запитаємо: “Чи можемо ми це виростити?”” (переклад наш. - О. П.). Тобто агентне моделювання в деякому сенсі можна розглядати як пробірку для вирощування живої соціальної клітини та вивчення іï властивостей. Це становить особливий інтерес, наприклад, тоді, коли нові технології відкривають нові можливості поведінки на мікрорівні, що може призводити до появи неочікуваних сценаріїв на макрорівні, які принципово не могли бути реалізовані в минулому.

Серед переваг агентного моделювання слід зазначити можливість комп'ютерного експериментування, що дає змогу досліджувати наслідки зміни параметрів системи. Поведінка складних систем потребує знання не одного, а різних сценаріїв розвитку системи, а також усвідомлення чутливості системи до незначних втручань.

Як і будь-яка модель, агентна модель $є$ спрощенням реальності, а також компромісом між реальністю у всій своїй складності і багатоаспектності та можливістю отримати результат, який допоміг би ухвалювати рішення в умовах складності і невизначеності. Перевірка результатів агентного моделювання на підставі реальних даних не досить коректна. Коли ми маємо справу зі складними системами, то те, що ми бачимо, - це реалізація одного з можливих сценаріїв поведінки. Агентне моделювання має більш важливий аспект дослідження - простір можливостей та досвід ухвалення рішень у ситуації «що буде, якщо?».

Відносини соціального обміну за своєю природою є конфліктними. Нерівномірний розподіл влади та ресурсів у суспільстві загострює 
конкуренцію, що часто змінює баланс сил між соціальними суб'єктами. Агенти борються за максимізацію доходу і мінімізацію витрат, що, своєю чергою, призводить до певного перерозподілу спільної сфери інтересів.

Конфліктні взаємодії інтенсивно вивчають у рамках теорії ігор (Axelrod, 1984; Myerson, 1991; Sigmund, 2010; Schelling, 1960), теорії складних систем (Byrne, 2013; Yaneer Bar-Yam, 2015), теорії динамічних систем (Coleman \& Nowak, 2010), теорії мереж (Barabasi, 2002; Jackson, 2008).

У цій роботі моделювання політики податків та субсидій проведено в рамках штучного суспільства, створеного в середовищі програмування NetLogo. Теоретичною основою $є$ математична модель конфліктної взаємодії (Koshmanenko, 2014). Підхід грунтується на інтерпретації протилежних сторін конфлікту як імовірнісного розподілу спірної території. Зручність задання динамічної системи конфлікту в термінах щільності розподілу полягає в можливості наочного описання поведінки складної системи на макрорівні в результаті процесу конфліктної боротьби між двома протидіючими субстанціями на мікрорівні. У цій роботі дослідницьку увагу спрямовано на розподіл спільної зони інтересів у результаті конфліктної взаємодії «витрати-винагороди». Якщо математична модель дозволяє отримати універсальні рівняння конфліктної динаміки, а також дослідити стани рівноваги, то агентне моделювання дає можливість експериментувати з параметрами системи та описувати динаміку системи, що є занадто складною математичною задачею, яка дуже часто не має аналітичного розв'язку.

Розглянемо модель суспільства, що складається $3 N$ агентів, кожен 3 яких має свою власну ймовірність отримання винагороди $\left(p_{i}, 0 \leq p_{i} \leq 1\right.$, $i=1, \ldots, N)$ і власний рівень витрат $\left(q_{i}, 0 \leq q_{i} \leq 1\right.$, $i=1, \ldots, N)$. Агенти вступають у відносини соціального обміну згідно з правилами конфліктної взаємодії, запропонованими В. Д. Кошманенком. Суть цієї взаємодії полягає в тому, що на кожному етапі часу в результаті конфлікту «витрати-винагороди» відповідні параметри кожного з агентів перераховуються за правилами (1), а потім нормуються 3 огляду на те, що їхні сумарні значення в масштабі суспільства залишаються незмінними.

$$
\begin{gathered}
p_{i}^{t+1}=\frac{p_{i}^{t}\left(1-q_{i}^{t}\right)}{z^{t}}, q_{i}^{t+1}=\frac{q_{i}^{t}\left(1-p_{i}^{t}\right)}{z^{t}}, p_{i}^{0}=p_{i}, \\
q_{i}^{0}=q_{i}, t=0,1 \ldots,
\end{gathered}
$$

де $z^{t}$ - нормуючий коефіцієнт.

Початкова модель складається 31000 агентів $(N=1000)$ трьох типів: багатії, середній клас i бідні. Параметри $p_{i}$ (ймовірність отримати винагороду) і $q_{i}$ (ймовірність витрат) задаються випадковим чином так, щоб

$$
\sum_{1}^{N} p_{i}=1 \text { i } \sum_{1}^{N} q_{i}=1 .
$$

В основі класифікації агентів лежить значення ерs $=1 / N$, а саме:

- якщо $p_{i} \geq e p s$, то агент належить до класу багатих (білий колір);

- якщо $p_{i}<e p s$ i $q_{i} \geq e p s$, то агент належить до класу бідних (чорний колір);

- в інших випадках агент належить до середнього класу (сірий колір).

Як свідчать результати моделювання, в довгостроковому періоді встановлюється рівновага, в якій соціальний розподіл $є$ практично рівномірним (рис. 1).

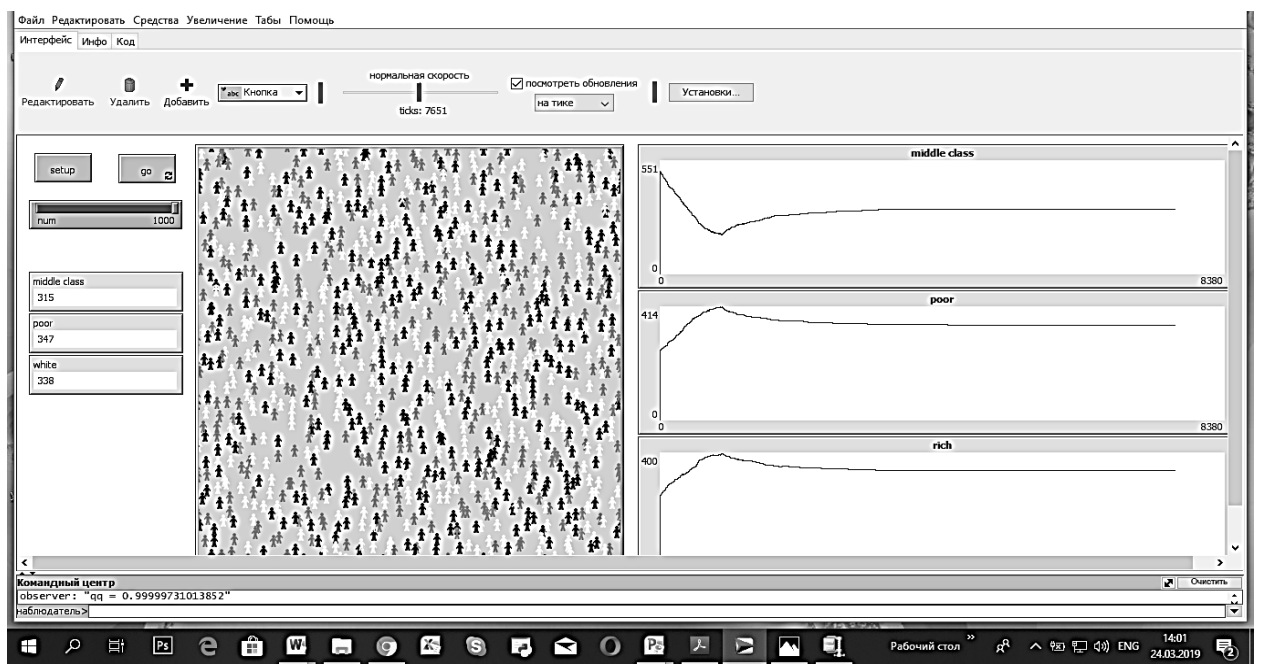

Рис. 1. Динаміка розподілу суспільного доходу в базовій моделі. Моделювання здійснювалось у NetLogo 6.0.2 
Наступним етапом комп'ютерних експериментів є запровадження зовнішнього втручання в механізм соціальної взаємодії у вигляді надання субсидій тим, хто опинився за межею бідності, яка визначається як ерs ${ }^{2}$. Бідні агенти на кожному етапі моделювання отримують деяку частку суспільного багатства (prich), яке визначається як сума $p_{i}$ всіх агентів, у яких $p>=e p s$, тобто

$$
p^{t+1}=p^{t}+\frac{\text { alpha }}{l} * \text { prich },
$$

де $l$ - кількість найбідніших агентів; alpha - параметр, що показує, яка частина суспільного доходу перерозподіляється на допомогу найбіднішим. Параметр задається повзунком, розташованим у вікні моделювання, $0<$ alpha $<1$.

Правило розподілу соціального доходу задається кодом у програмі NetLogo: set prich sum [p] of turtles with [ $p>=$ eps]

ask turtles with [p<eps $\wedge 2][\operatorname{set} p p+($ alpha /l) * prich ]

На кожному етапі застосовується процес нормалізаціі, що зменшує значення $p$ агентів системи так, щоб

$$
\sum_{1}^{N} p_{i}=1 .
$$

Як видно з рис. 2, у довгостроковій перспективі динаміка соціальної взаємодії $\epsilon$ нестабільною. Навіть маленьке значення параметра alpha значно порушує механізм взаємодії, роблячи поведінку агентів більш хаотичною та непередбачуваною. Зовнішня інтервенція, що мала на меті допомогти тим, хто опинився на соціальному дні, призвела до хаотичних флуктуацій. До того ж зі зростанням обсягу соціальної допомоги амплітуда флуктуацій стрімко зростає (рис. 3).

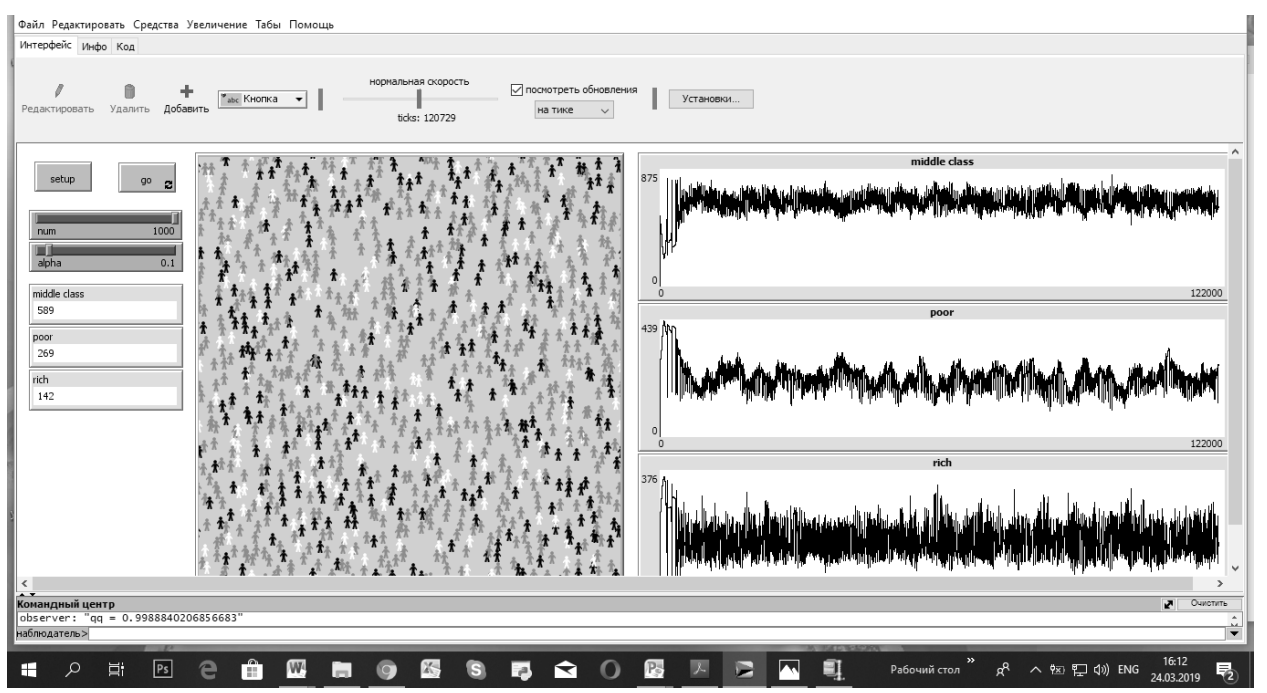

Рис. 2. Динаміка розподілу суспільного доходу у разі надання субсидій найбіднішій частині населення

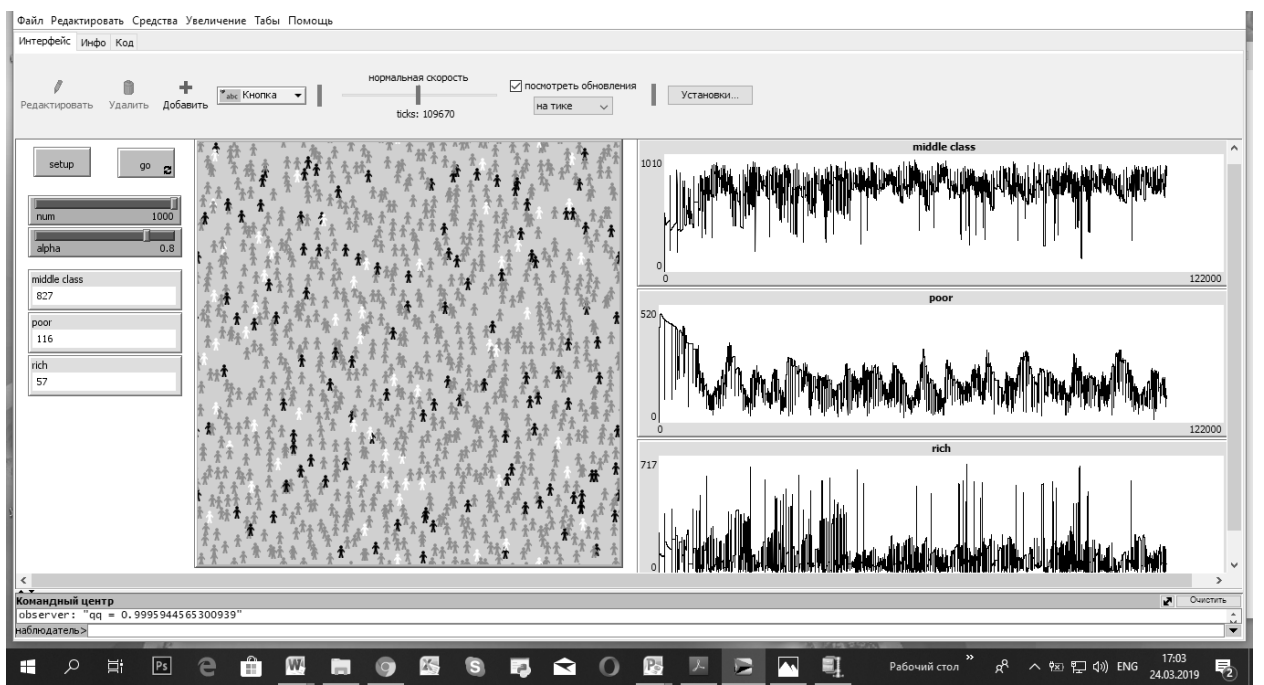

Рис. 3. Хаотизація динаміки соціальної взаємодії у разі значного збільшення субсидій 
Наступним кроком є побудова моделі створення ренти (rent-seeking model), яка досліджує динаміку соціальної взаємодії, коли частина суспільства має привілеї. Кількість «обраних» визначається повзунком (percent-selected). «Обрані» визначаються випадковим чином 3 агентів моделі.

Отже, кожен агент системи характеризується додатковим дихотомічним параметром social:

social = 1 у разі, якщо агент є «обраним»;

social $=0$ в іншому випадку.

У моделі, що розглядається, соціальна структура середнього класу деталізується на «економічно активних» (винагороди перевищують витрати) i «економічно пасивних» (витрати перевищують винагороди). У цьому разі структуру населення подано в таблиці.

$$
p^{t+1}=p^{t}+\operatorname{beta} \frac{(1-\text { alpha })}{l l} * \text { prich }
$$

де $l l$ - загальна кількість бідних агентів.

Правила розподілу суспільного пирога задаються в NetLogo кодом:

prich sum $[p]$ of turtles with [ social $=0$ and $p>=$ eps and $p>q]$

ask turtles with $[$ social $=1][\operatorname{set} p p+($ alpha $/ l) *$ prich ]

ask turtles with [social $=0$ and $p<$ eps $\wedge 2$ ] [set p p + (beta* $(1-$ alpha $) / l l) *$ prich]

Як видно з рис. 4, зовнішне втручання в механізм соціальної взаємодії призводить до суттєвих змін у соціальній структурі суспільства. Отримання багатства за рахунок інших призводить до знищення економічно активної частини

Таблиия. Соціальна структура населення

\begin{tabular}{|l|l|l|l|}
\hline \multicolumn{1}{|c|}{ Колір агентів } & \multicolumn{1}{|c|}{ Визначення } & \multicolumn{1}{c|}{ Інтерпретація } & Економічна активність \\
\hline Синій (blue) & $\mathrm{p} \geq 2 * \mathrm{eps}$ & клас багатих & - \\
\hline Зелений (green) & $\mathrm{eps}^{2}<\mathrm{p}<2 * \mathrm{eps}, \mathrm{p} \geq \mathrm{q}$ & середній клас & активні \\
\hline Коричневий (brown) & $\mathrm{eps}^{2}<\mathrm{p}<2 * \mathrm{eps}, \mathrm{p}<\mathrm{q}$ & середній клас & пасивні \\
\hline Чорний (black) & $\mathrm{p} \leq \mathrm{eps}^{2}$ & клас бідних & - \\
\hline
\end{tabular}

«Обрані» агенти на кожному етапі моделювання отримують деяку частку суспільного доходу (prich), яка визначається як сума $p_{i}$ всіх агентів, у яких $p>e p s^{2}$ i social $=0$, тобто

$$
p^{t+1}=p^{t}+\frac{\text { alpha }}{l} * \text { prich }
$$

де alpha - відсоткова ставка, виражена в частках (задається повзунком); $l$ - загальна кількість «обраних» агентів.

У моделі також передбачено соціальну допомогу бідним:

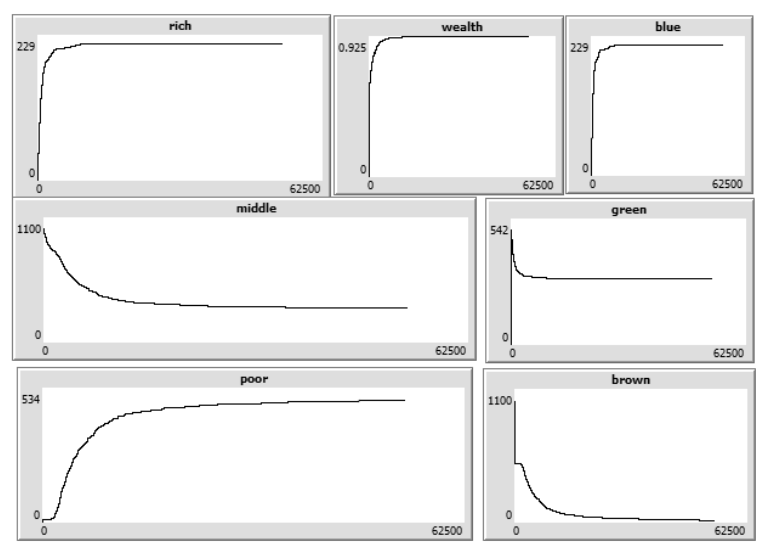

середнього класу (green), що стрімко зменшує суспільне багатство (wealth) і запускає механізм соціальних дотацій. Боротьба з бідністю в такій ситуації тримається на ефекті запізнення (лаговому ефекті), а в довгостроковому періоді призводить до суспільної деградації.

\section{Висновки}

Погляд на соціальну систему як на складну систему, елементи якої взаємопов'язані, взаємодіють один $з$ одним за певними правилами та

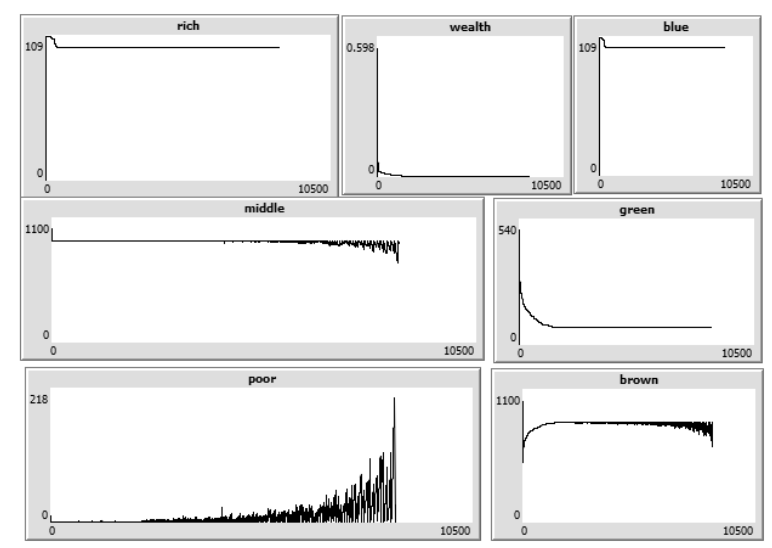

Рис. 4. Зміни в соціальній структурі суспільства

Ліворуч: базова модель (percent-selected $=0 \%$, alpha $=0$, beta $=0$ )

Праворуч: модель створення ренти (percent-selected $=10 \%$, alpha $=0.1$, beta $=0.1$ ) 
утворюють єдине ціле, привертає увагу до складних наслідків втручання в правила гри.

Стан соціальної рівноваги «витрати = винагороди» припиняє розвиток системи. Тому нерівномірність розподілу, гетерогенність соціальних агентів є драйверами соціальної взаємодії, на основі якої виникає певний соціальний порядок.

Але зовнішне втручання в правила гри, в результаті якого частину суспільного доходу перерозподіляють на користь певних соціальних груп, змінює баланс сил, що підтримує наявний соціальний порядок.

Результати аналізу показали, що навіть незначне зовнішне втручання в процес соціального обміну:

- у вигляді субсидій певній частині суспільства веде до дестабілізації;

- у вигляді виплати ренти певній частині суспільства, що має привілеї, призводить до суттєвих змін у соціальній структурі суспільства, які знищують середній клас та поляризують суспільство.

Можливо, врахування інших факторів і правил поведінки дасть додаткові уявлення про сценарії соціальної динаміки, але механізм соціального обміну, як показало дослідження, $є$ дуже чутливим до будь-якого зовнішнього втручання, яке врешті-решт зводиться до зміни щільності розподілу спільної зони інтересів. У такій ситуації доцільно стежити за крихкістю системи (system fragility), яка зростає.

Це, своєю чергою, вимагає адекватних методів дослідження. Статистичний аналіз соціологічних даних припускає, що можна зробити висновки про ціле через дослідження властивостей окремих його частин. Але це не завжди так, свідченням чого є неспроможність передбачити соціальні вибухи, напередодні яких дані не сигналізували жодної тривоги. Ідею реформування традиційної освіти соціологів та привнесення в підготовку фахівців комп'ютерного моделювання відстоює колишній президент Свропейської асоціації соціального моделювання Фламініо Скуаззоні (Squazzoni, 2015), який вважає це необхідним кроком для розуміння сьогоднішніх соціальних явищ.

Сучасний стан України характеризується соціальною нестабільністю, посиленням процесів хаотизації динаміки соціальної взаємодії, зростанням чутливості до внутрішніх і зовнішніх втручань, стрімким зменшенням суспільного багатства, загостренням конфліктів і зростанням невизначеності. У такій ситуації використання комп'ютерного моделювання, зокрема агентного моделювання, виявляється надзвичайно актуальним.

\section{Список використаної літератури}

Плотинский, Ю. М. (2001). Модели сочиальных проиессов. Москва: Логос.

Сатаров, Г. (2006, 28 апреля). Наследие Просвещения. Коммерсанть, 76 (3407). Получено с http://kommersant.ru/doc/ 670503/print

Центр Разумкова. (2019). Рівень довіри до суспільних інститутів та електоральні орієнтації громадян України. Отримано $3 \mathrm{http} / /$ razumkov.org.ua/uploads/socio/2019_02_press.pdf

Axelrod, R. (1984). The Evolution of Cooperation. Basic Books, New York.

Barabasi, A.-L. (2002). Linked: The New Science of Networks. Cambridge, MA: Perseus Publishing.

Byrne, D., \& Callaghan, G. (2013). Complexity Theory and the Social Sciences. The state of the art. Abingdon, Oxon: Routledge.

Christakis, N. A., \& Fowler, J. H. (2009). Connected: The Surprising Power of Our Social Networks and How They Shape Our Lives. New York: Little Brown. DOI: https://doi.org/10.1163/1568 $53710 \times 531267$

Cingano, F. (2014). Trends in Income Inequality and Its Impact on Economic Growth. OECD SEM Working Paper No. 163. Retrieved from www.oecd.org/els/workingpapers

Epstein, J. M. \& Axtell, R. (1996). Growing artificial societies: Social science from the bottom up. Washington, DC: Brookings Institution Press. DOI: https://doi.org/10.7551/mitpress/3374.001.0001

Fellman, P., Bar-Yam, Y., \& Minai, A. A. (2015). Conflict and Complexity: Countering Terrorism, Insurgency, Ethnic and Regional Violence. New York: Springer. DOI: https://doi. org/10.1007/978-1-4939-1705-1

Jackson, M. O. (2008). Social and Economic Networks. Princeton, NJ: Princeton University Press.

Koshmanenko, V. (2014). Existence theorems of the $\omega$-limit states for conflict dynamical systems. Meth. Funct. Anal. Topology, 20 (4), 379-390.
Myerson, R. B. (1991). Game Theory: Analysis of Conflict. Cambridge MA: Harvard University Press.

Nowak, M. A. (2006). Five rules for the evolution of cooperation. Science (New York, N.Y.), 314(5805), 1560-1563. DOI: https:// doi.org/10.1126/science. 1133755

OECD. (2014). FOCUS on Inequality and Growth. Retrieved from https://www.oecd.org/social/Focus-Inequality-andGrowth-2014.pdf

Page, B. I., \& Gilens, M. (2017). Democracy in America?: What has Gone Wrong and What We Can Do About It? Chicago, IL: University of Chicago Press. DOI: https://doi.org/10.7208/ chicago/9780226509013.001.0001

Schelling, T. C. (1960). The Strategy of Conflict. Cambridge MA: Harvard University Press.

Sigmund, K. (2010). The Calculus of Selfishness. New Jersey: Princeton University Press.

Squazzoni, F. (2012). Agent-Based Computational Sociology. Chichester:Wiley. DOI: https://doi.org/10.1002/9781119954200

Squazzoni, F. (2015). Stimulating simulations. Pan European Networks: Science \& Technology, 14, 68-70. Retrieved from www.paneuropeannetworks.com

Stiglitz, J. E., et al. (2015). Rewriting the Rules of the American Economy. A Report of Roosevelt Institute. New York.

Vallacher, R., Coleman, P. T., Nowak, A., \& Bui-Wrzosinska, L. (2010). Rethinking intractable conflict: The perspective of dynamical systems. American Psychologist, 65 (4), May-Jun., 262-278. DOI: https://doi.org/10.1037/a0019290

Wiesner, K., et al. (2019). Stability of democracies: a complex systems perspective. European Journal of Physics, 40 (1). Retrieved from https://iopscience.iop.org/article/10.1088/13616404/aaeb4d/meta

World Values Survey. (2014). World values survey: all rounds. Technical Report. Retrieved from http://worldvaluessurvey.org 


\section{References}

Axelrod, R. (1984). The Evolution of Cooperation. Basic Books, New York.

Barabasi, A.-L. (2002). Linked: The New Science of Networks. Cambridge, MA: Perseus Publishing.

Byrne, D., \& Callaghan, G. (2013). Complexity Theory and the Social Sciences. The state of the art. Abingdon, Oxon: Routledge.

Christakis, N. A., \& Fowler, J. H. (2009). Connected: The Surprising Power of Our Social Networks and How They Shape Our Lives. New York: Little Brown. DOI: https://doi.org/10.1163/1568 $53710 \times 531267$

Cingano, F. (2014). Trends in Income Inequality and Its Impact on Economic Growth. OECD SEM Working Paper No. 163. Retrieved from www.oecd.org/els/workingpapers

Epstein, J. M. \& Axtell, R. (1996). Growing artificial societies: Social science from the bottom up. Washington, DC: Brookings Institution Press. DOI: https://doi.org/10.7551/mitpress/3374.001.0001

Fellman, P., Bar-Yam, Y., \& Minai, A. A. (2015). Conflict and Complexity: Countering Terrorism, Insurgency, Ethnic and Regional Violence. New York: Springer. DOI: https://doi. org/10.1007/978-1-4939-1705-1

Jackson, M. O. (2008). Social and Economic Networks. Princeton, NJ: Princeton University Press.

Koshmanenko, V. (2014). Existence theorems of the $\omega$-limit states for conflict dynamical systems. Meth. Funct. Anal. Topology, 20 (4), 379-390.

Myerson, R. B. (1991). Game Theory: Analysis of Conflict. Cambridge MA: Harvard University Press.

Nowak, M. A. (2006). Five rules for the evolution of cooperation. Science (New York, N.Y.), 314 (5805), 1560-1563. DOI: https:// doi.org/10.1126/science. 1133755

OECD. (2014). FOCUS on Inequality and Growth. Retrieved from https://www.oecd.org/social/Focus-Inequality-andGrowth-2014.pdf
Page, B. I., \& Gilens, M. (2017). Democracy in America?: What has Gone Wrong and What We Can Do About It? Chicago, IL: University of Chicago Press. DOI: https://doi.org/10.7208/ chicago/9780226509013.001.0001

Plotinskiy, Yu. M. (2001). Modeli sotsialnyh protsessov. Moscow: Logos [in Russian].

Razumkov centre. (2019). Riven doviry do suspilnykh instytutiv ta elektoralni oriientatsii hromadian Ukrainy. Retrieved from http:/ razumkov.org.ua/uploads/socio/2019_02 press.pdf [in Ukrainian].

Satarov, G. (2006, April 28). Nasledie Prosvescheniya. Kommersant, 76 (3407). Retrieved from http://kommersant.ru/doc/670503/ print [in Russian].

Schelling, T. C. (1960). The Strategy of Conflict. Cambridge MA: Harvard University Press.

Sigmund, K. (2010). The Calculus of Selfishness. New Jersey: Princeton University Press.

Squazzoni, F. (2012). Agent-Based Computational Sociology. Chichester: Wiley. DOI: https://doi.org/10.1002/9781119954200

Squazzoni, F. (2015). Stimulating simulations. Pan European Networks: Science \& Technology, 14, 68-70. Retrieved from www.paneuropeannetworks.com

Stiglitz, J. E., et al. (2015). Rewriting the Rules of the American Economy. A Report of Roosevelt Institute. New York.

Vallacher, R., Coleman, P. T., Nowak, A., \& Bui-Wrzosinska, L. (2010). Rethinking intractable conflict: The perspective of dynamical systems. American Psychologist, 65 (4), May-Jun., 262-278. DOI: https://doi.org/10.1037/a0019290

Wiesner, K., et al. (2019). Stability of democracies: a complex systems perspective. European Journal of Physics, 40 (1). Retrieved from https://iopscience.iop.org/article/10.1088/13616404/aaeb4d/meta

World Values Survey. (2014). World values survey: all rounds Technical Report. Retrieved from http://worldvaluessurvey.org

\section{O. Pugachova}

\section{AGENT-BASED SIMULATION OF REVENUE POLICY}

The main research attention is focused on social interaction as a complex system of give-and-take actions with different ways to balance costs and rewards and on the problem of increasing the income inequality.

The current investigation analyzes the influence of tax-and-transfer policy on the social structure of society. Different tax regimes were tested by means of computer experiments. The mathematical model of conflict interaction (Koshmanenko, 2014) is the theoretical basis of the agent-based simulation in NetLogo.

It is shown that intervention into the process of conflict interactions aimed in support of those who are at the social "bottom" results in the emergence of fluctuations. Even a small value of external replenishment destroys the stable mechanism of internal redistribution and leads to an unpredictable chaotic behaviour. Moreover, the amplitude of these fluctuations is growing rapidly as the scope of assistance increases.

The current research tries to give insight into the influence of rent-seeking practice on the social structure of society. Rent-seeking means the practice of obtaining wealth not through economically valuable activity but by extracting it from others (privileges, tax havens, offshores, etc.). The analysis of the results of computer simulation demonstrates qualitative changes in the social structure of society, namely:

- the rich class includes only "selected" agents;

- economically active agents of the middle class practically disappear while the number of economically passive agents increases;

- the number of those who are under the poverty line is growing rapidly.

This paper is also aimed at highlighting the potential of agent-based modelling as a research tool for analyzing complex social systems at the edge of chaos and drawing attention to the necessity of filling the gap between traditional social education and computer modelling.

Keywords: complex system, conflict interaction, equilibrium, social order, rent-seeking model. 